\title{
Elevated cell migration, invasion and tumorigenicity in human KB carcinoma cells transfected with COX-2 cDNA
}

\author{
KAZUKI TAKAOKA ${ }^{1}$, HIROMITSU KISHIMOTO ${ }^{1}$, EMI SEGAWA ${ }^{1}$, SUSUMU HASHITANI $^{1}$, \\ YUSUKE ZUSHI $^{1}$, KAZUMA NOGUCHI ${ }^{1}$, KAZUNARI SAKURAI ${ }^{1,2}$ and MASAHIRO URADE ${ }^{1}$ \\ Departments of ${ }^{1}$ Oral and Maxillofacial Surgery, ${ }^{2}$ Surgical Pathology, Hyogo College of Medicine, \\ 1-1 Mukogawa-cho, Nishinomiya, Hyogo 663-8501, Japan
}

Received June 19, 2006; Accepted August 3, 2006

\begin{abstract}
In order to investigate the involvement of cyclooxygenase (COX)-2 in cell growth and invasion of oral cancer, a human epidermoid carcinoma cell line KB minimally expressing COX-2 protein was transfected with $\mathrm{COX}-2$ cDNA and these activities were compared with mock-transfected $\mathrm{KB}$ in vitro and in vivo. $\mathrm{KB} / \mathrm{COX}-2$ clones showed a similar growth rate in vitro compared to $\mathrm{KB} /$ neo clones, but demonstrated significantly increased $\mathrm{PGE}_{2}$ production, cell migration and invasion. These $\mathrm{KB} / \mathrm{COX}-2$ clones markedly expressed MMP-9, pro-MMP-2 and activated-MMP-2 as compared to $\mathrm{KB} /$ neo clones in gelatin zymography. Western blot analysis showed that expression of MT1-MMP, Rho and $\mathrm{Rac} 1$ in $\mathrm{KB} / \mathrm{COX}-2$ clones were stronger than that in $\mathrm{KB} /$ neo clones, but expression of TIMP-1 and TIMP-2 were weaker in $\mathrm{KB} / \mathrm{COX}-2$ clones than in $\mathrm{KB} /$ neo clones. When these cells were inoculated subcutaneously into nude mice, tumorigenicity and tumor growth were significantly elevated in $\mathrm{KB} / \mathrm{COX}-2$ tumors than in $\mathrm{KB} /$ neo tumors, and the gelatinase activity was much stronger in $\mathrm{KB} / \mathrm{COX}-2$ tumor tissues than in $\mathrm{KB} /$ neo tumor tissues in film in situ zymography. The orthotopic inoculation of cells to the oral floor showed that local invasion was pronounced in $\mathrm{KB}$ / COX-2 tumors. These results indicated that overexpression of COX-2 elevated tumorigenicity, tumor growth and invasion of human KB carcinoma cells via up-regulated MMP and Rho family small GTPases and down-regulated TIMP activities.
\end{abstract}

\section{Introduction}

Cyclooxygenase $(\mathrm{COX})$ is the rate-limiting enzyme in the biosynthesis of prostaglandins from arachidonic acid. Two

Correspondence to: Dr Masahiro Urade, Department of Oral and Maxillofacial Surgery, Hyogo College of Medicine, 1-1 Mukogawacho, Nishinomiya, Hyogo 663-8501, Japan

E-mail: uradem@hyo-med.ac.jp

Key words: COX-2, cell migration, invasion, tumorigenicity, human $\mathrm{KB}$ carcinoma isoforms of the COX enzyme exist, COX-1 and COX-2, and they have been postulated to be target molecules for nonsteroidal anti-inflammatory drugs (NSAIDs). COX-1 is constitutively expressed in most tissues and appears to be a housekeeping enzyme responsible for various physiological functions, such as cytoprotection in the stomach, vasodilation in the kidney, and production of pro-aggregatory prostanoid thromboxane by platelets (1). On the other hand, COX-2 is induced by stimuli such as mitogens, cytokines, growth factors and tumor promoters, and is up-regulated at the sites of inflammation and in various cancer tissues; colon (2), stomach (3), breast (4), lung (5), esophagus (6), pancreas (7), urinary bladder (8), prostate (9) and skin (10). Former studies concerning involvement of COX-2 in cancer pathogenesis elucidated that COX-2 inhibits apoptosis (11) and immune surveillance (12), promotes angiogenesis (13), increases cancer invasiveness and metastasis (14) and regulates cell differentiation (15). In head and neck carcinoma several investigators have shown that expression of COX-2 is upregulated (16-18), but its significance in relation to tumor cell migration, invasion and metastasis is not fully understood. Therefore, we investigated the effect of COX-2 overexpression in head and neck cancer cells on cell growth and invasive potentials in vitro and in vivo.

In this study, human $\mathrm{KB}$ carcinoma cell line minimally expressing COX-2 protein expression was transfected with COX-2 cDNA, and isolated clones with high COX-2 expression were compared with mock-infected clones in cell growth and invasion in vitro and in transplantable tumor model in nude mice. Consequently, it was indicated that overexpression of COX-2 promotes cell migration in vitro and increases tumorigenicity, tumor growth and local invasion in nude mice, via up-regulated matrix metalloproteinase (MMP), Rho family small GTPases and down-regulated tissue inhibitor of metalloproteinase (TIMP) activities.

\section{Materials and methods}

Cell lines and cell culture. Human KB carcinoma cell line (19) derived from epidermoid carcinoma of the floor of the mouth was used in this study. KB cells were grown in Dulbecco's modified Eagle's MEM (DMEM, Nissui Pharmaceutical Co., Tokyo, Japan) supplemented with $10 \%$ fetal bovine serum (HyClone Laboratories, Logan, UT, USA) and 
$4 \mathrm{mM}$ L-glutamine as growth medium at $37 \%$ in a $5 \% \mathrm{CO}_{2}$ incubator. This cell line was routinely subcultured with EDTAtrypsin mixture. In preliminary experiment, we found that $\mathrm{KB}$ cells lacked or minimally possessed COX-2 protein in Western blot analysis.

COX-2 cDNA transfection. Cells were transfected with pSG5COX-2 plasmid containing a full-length human COX-2 cDNA (20) (a gift of Dr R. Kulmacz, University of Texas Medical School, Houston, TX) and pcDNA3 containing a neomycinresistant marker by using calcium phosphate method as described previously (21). Positive transfectants were selected in DMEM containing $500 \mu \mathrm{g} / \mathrm{ml}$ geneticin (Cosmo Bio Co., Tokyo, Japan) and separate colonies were isolated using cloning cylinders.

Cell growth assay. Cells were plated at $2.5 \times 10^{3}$ cells/well in a $100 \mu 1$ volume in 96-well plates and cultured in growth medium at $37^{\circ} \mathrm{C}$. Cell growth was assessed by 3(4,5-dimethylethiazoly 1-2-)2,5-diphonyl tetrazolium bromide (MTT) assay after 1, 3,5 and 7 days of incubation, as described previously (22).

Prostaglandin $E_{2}\left(P G E_{2}\right)$ immunoassay. Cells were plated at $2 \times 10^{4}$ cells/well in $1 \mathrm{ml}$ volume in 24 -well plates and grown at $37^{\circ} \mathrm{C}$ for $24 \mathrm{~h}$ in growth medium. The medium was discarded and $1 \mathrm{ml}$ of serum-free fresh medium was added to each well, and then conditioned medium was collected after $15 \mathrm{~min}$. $\mathrm{PGE}_{2}$ assay was performed as indicated in a protocol of prostaglandin $\mathrm{E}_{2}$ EIA kit (Cayman Chemical, Ann Arbor, MI, USA), as described previously (22).

Wound healing assay. Cells were plated at $7.5 \times 10^{5}$ cells/dish in 60-mm fibronectin-coated dishes (Asahi Techno Glass Co., Tokyo, Japan). After 6-h incubation, wound healing assay was performed. Scratch wounds were created by scraping confluent cell monolayers with a sterile pipette tip. After 24-h incubation, cell migration was quantified by measuring from wound edge to edge.

Invasion assay. Cell invasion assay was carried out using BioCoat Matrigel Invasion Chambers (Becton Dickinson Labware, Bedford, MA, USA) consisting of transwell membrane filter inserts in a 24-well tissue culture plate. The transwell filter has $8 \mu \mathrm{m}$ pore size membrane coated with matrigel. Five thousand cells were seeded in the upper chamber of the transwell with serum-free DMEM, and DMEM containing $10 \%$ FBS were added to the lower chamber. After 24-h incubation, non-invading cells were removed by wiping the upper side of the membrane, and invaded cells were fixed and stained with Diff-Quick kit (Kokusaishiyaku Co., Kobe, Japan). The number of invaded cells per membrane was counted under a light microscope at x200 magnification in each four fields of triplicate membranes.

Western blot analysis. Cells were lysed in a lysis buffer composed of $\mathrm{Mg}^{2+}$ - and $\mathrm{Ca}^{2+}$ - free phosphate-buffered saline (PBS) containing $20 \mathrm{mM}$ Tris-HCl, pH 8.0, 1\% NP40, $150 \mathrm{mM}$ $\mathrm{NaCl}, 1 \mathrm{mM}$ EDTA, 10\% glycerol, 0.1\% B-mercaptoethanol, $0.5 \mathrm{mM}$ dithiothreitol, and a mixture of proteinase inhibitors consisting of $1 \mathrm{mM}$ phenylmethylsulfonyl fluoride, $10 \mu \mathrm{g} / \mathrm{ml}$ aprotinin, $5 \mu \mathrm{g} / \mathrm{ml}$ leupeptin, $5 \mathrm{mM}$ benzamidine, $1 \mu \mathrm{g} / \mathrm{ml}$ pepstatin, $2 \mu \mathrm{g} / \mathrm{ml}$ antipain hydrochloride (Boehringer, Mannheim, Germany), $50 \mu \mathrm{M}$ 4-(2-aminoethyl)-benzenesulfonyl fluoride hydrochloride (Wako Pure Chemical Industries, Ltd., Osaka, Japan), 2 mM sodium orthovanadate (Sigma-Aldrich Co., St. Louis, MO, USA), and $20 \mathrm{U} / \mathrm{ml}$ ulinastatin (Mochida Pharmaceutical, Tokyo, Japan). The lysate containing $15 \mu \mathrm{g}$ protein was electrophoresed in a $10-20 \%$ gradient SDS-PAGE mini gel (Bio-Rad, Chicago, IL, USA) and blotted onto a PVDF membrane using Multiphor II (Amersham Pharmacia Biotech, Buchinghamshire, UK) for $30 \mathrm{~min}$. The blotted membrane was blocked with 5\% skim milk in $10 \mathrm{mM}$ Tris-HCl, pH 7.2, containing $150 \mathrm{mM} \mathrm{NaCl}$ and $0.5 \%$ Tween-20 and incubated with primary antibodies $(0.1-1 \mu \mathrm{g} / \mathrm{ml})$ described below at $4^{\circ} \mathrm{C}$ for $16 \mathrm{~h}$. The membrane was then incubated with alkaline phosphatase-conjugated secondary antibodies $(0.02 \mu \mathrm{g} / \mathrm{ml})$ described below for $4 \mathrm{~h}$ at room temperature. The membrane was rinsed, treated with nitroblue tetrazolium (Sigma-Aldrich) and 5-bromo-4-chloro3-indolyl phosphate (Sigma-Aldrich) to visualize protein bands. The primary antibodies used were goat polyclonal antibody against COX-2, COX-1, RhoA and actin, and rabbit polyclonal antibody against Rac1 and Cdc42 (Santa Cruz Biotechnology, Santa Cruz, CA, USA), and mouse monoclonal antibodies against human MT1-MMP, TIMP-1, TIMP-2 (Daiichi Fine Chemical Co. Ltd., Toyama, Japan). The secondary antibodies used were anti-goat, -rabbit or -mouse IgGs conjugated with alkaline phosphatase (Santa Cruz Biotechnology). Actin was used as internal control.

Gelatin zymography. The culture media of cells in subconfluent condition were replaced with serum-free DMEM, and the cells were cultured for further $24 \mathrm{~h}$. The culture supernatants were collected as conditioned medium after centrifugation at $150 \mathrm{x} \mathrm{g}$ for $5 \mathrm{~min}$ to remove the debris. Because the culture supernatants contained only a small amount of protein, they were concentrated using a Centricon concentrator (Centricon YM-10; Millipore Co., Bedford, MA, USA) by centrifugation at $5000 \mathrm{x} \mathrm{g}$ for $30 \mathrm{~min}$. The protein concentrated $(10 \mu \mathrm{g})$ was mixed with non-reducing sample buffer $(62.5 \mathrm{mM}$ Tris- $\mathrm{HCl}$, $\mathrm{pH} 6.8,10 \%$ glycerol, $0.00125 \%$ bromophenol blue and $2 \%$ SDS) and electrophoresed at $4{ }^{\circ} \mathrm{C}$ on a $7.5 \%$ polyacrylamide gel containing $0.1 \%$ SDS and $0.1 \%$ gelatin. After electrophoresis, the gel was washed twice with rinsing buffer $(50 \mathrm{mM}$ Tris- $\mathrm{HCl}$, pH 7.5, 2.5\% Triton X-100, $5 \mathrm{mM} \mathrm{CaCl}_{2}, 1 \mu \mathrm{M}$ $\mathrm{ZnCl}_{2}, 0.05 \% \mathrm{NaN}_{3}$ ) at room temperature for $1 \mathrm{~h}$ to remove SDS. Strips of the gel were incubated at $37^{\circ} \mathrm{C}$ for $24 \mathrm{~h}$ in the reaction buffer for assaying gelatinolytic activity $(50 \mathrm{mM}$ Tris- $\mathrm{HCl}, \mathrm{pH} 7.5,5 \mathrm{mM} \mathrm{CaCl} 2,1 \mu \mathrm{M} \mathrm{ZnCl}_{2}, 0.05 \% \mathrm{NaN}_{3}$ ). After the gel strips were stained with staining solution $(0.1 \%$ Coomassie brilliant blue, $50 \%$ methanol and $20 \%$ acetic acid), those were destained in $30 \%$ methanol and 5\% acetic acid. The proteolytic activity appeared as clear bands on blue background.

Tumor formation in nude mice. Cells $\left(10^{5}\right.$ or $\left.10^{6}\right)$ were inoculated subcutaneously into the flanks of 5-week-old female nude mice (BALB/C nu/nu; Oriental Yeast Ltd., Osaka, Japan). Tumorigenicity and tumor growth at the inoculated sites were examined and tumor size was measured by using 


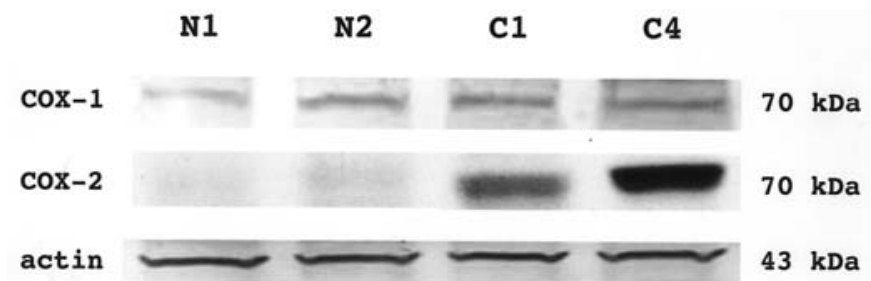

Figure 1. Expression of $\mathrm{COX}-1$ and $\mathrm{COX}-2$ protein in $\mathrm{KB} / \mathrm{COX}-2(\mathrm{C} 1, \mathrm{C} 4)$ and $\mathrm{KB} /$ neo $(\mathrm{N} 1, \mathrm{~N} 2)$ clones in Western blot.

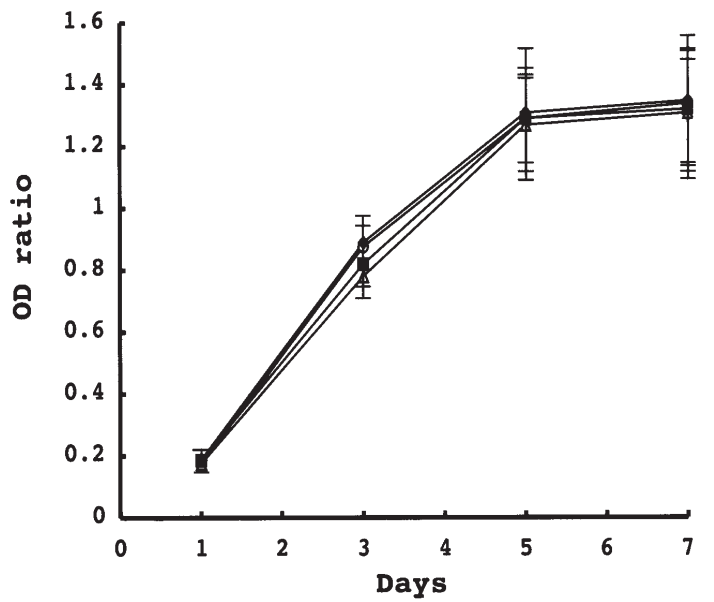

Figure 2. Growth curves of KB/COX-2 and KB/neo clones. Cells were plated at a density of $2.5 \times 10^{3}$ cells/well in growth medium and incubated at a $37^{\circ} \mathrm{C}$ in a $5 \% \mathrm{CO}_{2}$ incubator. Cell growth was determined by MTT assay at intervals. o, N1; $\Delta, \mathrm{N} 2 ; \bullet, \mathrm{C} 1 ; \boldsymbol{m}, \mathrm{C} 4$. Data represent mean \pm SD of 6 -wells.

calipers once a week. The relative tumor weight $(\mathrm{mg})$ was calculated by using the formula: $\mathrm{a}^{2} \mathrm{x} b / 2$, where $\mathrm{a}$ is the width in $\mathrm{mm}$ and $\mathrm{b}$ is the length in $\mathrm{mm}$, according to the method of Battelle Columbus Laboratories (23). To examine the local tumor invasion, the orthotopic inoculation of $10^{5}$ cells to the oral floor of nude mice was also performed.
Histological and immunohistochemical studies. Tissue specimens were fixed in $10 \%$ formalin, embedded in paraffin, and cut into $4-\mu \mathrm{m}$-thick sections according to conventional procedures. Histological examination was performed by H\&E stain. For immunohistochemical studies, a modification of the streptavidin-biotin-peroxidase complex (SABC) method (24) was employed by using rabbit polyclonal antibody against human COX-2 (IBL, Gunma, Japan) as described previously (25). Non-immunized rabbit serum was used as negative control.

Film in situ zymography. To examine the localization of gelatinase activity in tumor tissues, film in situ zymography was performed. MMP in situ Zymo-Film (Fuji Photo Film Co., Ltd. Tokyo, Japan) coated with a gelatin base emulsion was used to detect the gelatinase activity in the underlying tissue. Also, MMP-PT in situ Zymo-Film coated with 1,10phenanthrolin (an MMP inhibitor) was used as the control. A $4-\mu \mathrm{m}$-thick frozen section was placed onto the film, incubated at $37^{\circ} \mathrm{C}$ for $12 \mathrm{~h}$, and then stained with $1 \%$ amido black (Nacalai, Kyoto, Japan). Gelatinolysis was detected as the disappearance of amido black staining.

Statistical analysis. Statistical analysis was done by using the Student's t-test. Differences were considered significant when the $\mathrm{p}$-value was $<0.05$.

\section{Results}

Isolation of cell clones overexpressing COX-2 protein. Overexpression of COX-2 protein was seen in two clones among 5 separate clones transfected with COX-2 cDNA by Western blot. We isolated and designated these two clones as $\mathrm{KB} /$ COX-2 clone 1 (C1) and KB/COX-2 clone 4 (C4), and also isolated two neomycin-transfected clones, $\mathrm{KB} /$ neo clone 1 (N1) and KB/neo clone 2 (N2) as controls. KB/COX-2 clones showed about 3 - to 4 -fold increase of COX-2 protein expression and slightly increase of COX-1 protein expression as compared to $\mathrm{KB} /$ neo clones (Fig. 1). There was no apparent
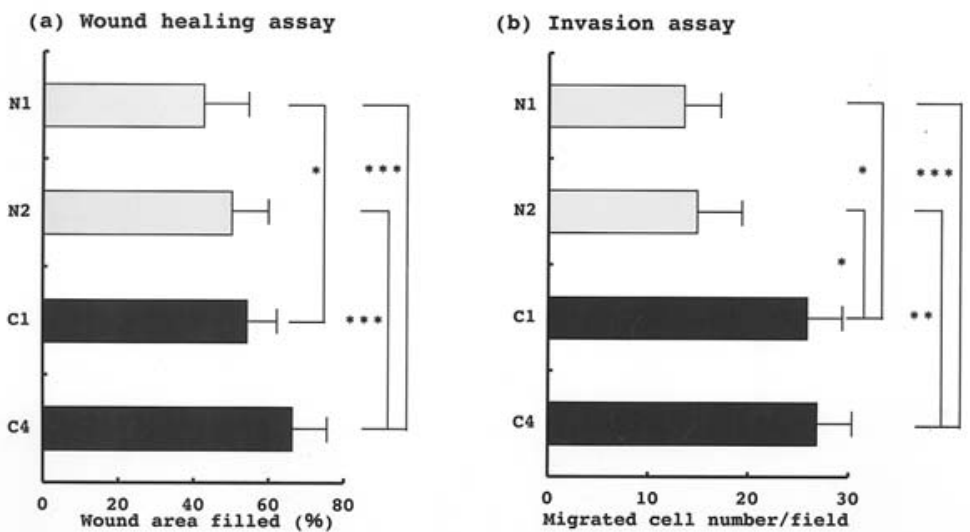

Figure 3. Wound healing assay and Matrigel invasion assay in KB/COX-2 and KB/neo clones. (a) Wound healing assay was performed using scratch wounds formed in confluent cell monolayers on $60-\mathrm{mm}$ fibronectin-coated dishes. Cell migration was quantified by measuring from edge to edge after $24-\mathrm{h}$ incubation. Data represent mean \pm SD of 10 determinations. (b) Cell invasion assay was performed using Matrigel invasion chambers. Twenty-five thousand cells were seeded in the upper chamber with serum-free DMEM, and DMEM containing 10\% FBS were added to the lower chamber. After 24-h incubation, invaded cells through matrigel-coated membrane were counted under a light microscope at x 200 magnification in each four fields of triplicate membranes. Data represent mean \pm SD of 12 determinations. ${ }^{*} \mathrm{p}<0.05,{ }^{* *} \mathrm{p}<0.01,{ }^{* * *} \mathrm{p}<0.005$. 
(a)

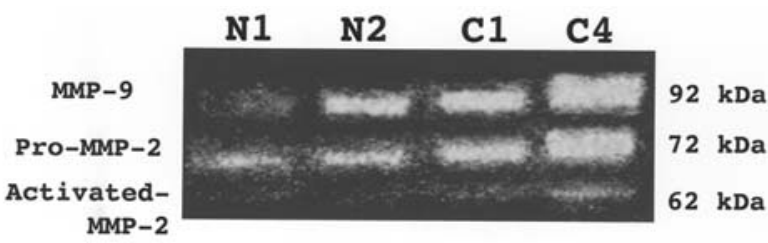

(b)

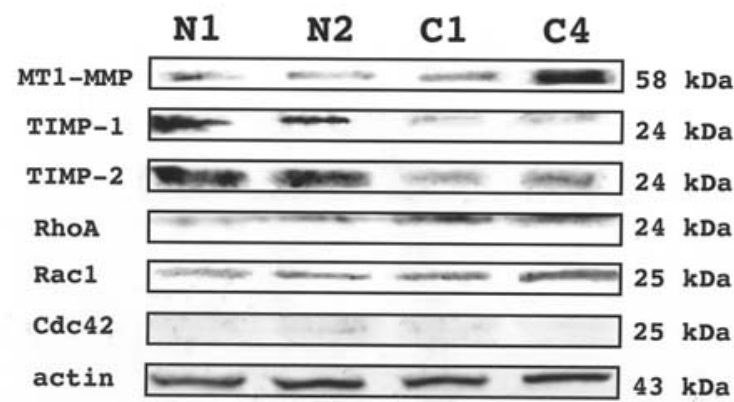

Figure 4. Gelatin zymography and Western blot for MMPs and TIMPs in KB/ COX-2 and KB/neo clones. (a) Gelatin zymography was performed to detect MMP-2 and MMP-9 using concentrated conditioned media of cell clones as described in the Materials and methods. (b) Expressions of MT1-MMP, TIMP-1, TIMP-2, RhoA, Rac1 and Cdc42 were examined by Western blot using monoclonal or polyclonal antibodies against those proteins.

morphological change between $\mathrm{KB} / \mathrm{COX}-2$ and $\mathrm{KB} / \mathrm{neo}$ clones. In cell growth curve, $\mathrm{KB} / \mathrm{COX}-2$ and $\mathrm{KB} /$ neo clones showed a similar growth rate and there was no significant difference between them (Fig. 2). However, $\mathrm{PGE}_{2}$ production was much more in $\mathrm{KB} / \mathrm{COX}-2$ clones than $\mathrm{KB} /$ neo clone (N1, 5.2 $\pm 1.2 \mathrm{pg} / 10^{3}$ cells; N2, $4.3 \pm 1.3 \mathrm{pg} / 10^{3}$ cells; $\mathrm{C} 1$, $7.3 \pm 1.8 \mathrm{pg} / 10^{3}$ cells; $\mathrm{C} 4,17.1 \pm 2.8 \mathrm{pg} / 10^{3}$ cells).
Increased cell migration in $\mathrm{KB} / \mathrm{COX}-2$ clones. To investigate the effect of COX-2 overexpression on tumor cell migration, wound healing assay and Matrigel invasion assay were employed. KB/COX-2 clones showed increased cell migration and filled scratch wound faster than did KB-neo clones (Fig. 3a). In addition, KB/COX-2 clones demonstrated a significantly increased ability to migrate through Matrigel invasion chambers as compared to $\mathrm{KB} /$ neo clones (Fig. 3b). Thus, COX-2 plays an important role in promoting cell migration of human KB carcinoma cells.

Elevated activity of metalloproteinases and Rho family small GTPases in $\mathrm{KB} / \mathrm{COX}-2$ clones. When gelatin zymography was performed using conditioned media from the cell clones, 92-, 72- and 62-kd bands exhibiting gelatin-degrading activity were detected. The 92-, 72-, and 62-kd bands were consistent with MMP-9, pro-MMP-2, and activated-MMP-2, respectively. These bands were thicker in $\mathrm{KB} / \mathrm{COX}-2$ clones than in $\mathrm{KB} /$ neo clones, indicating elevated activity of MMP-9, pro-MMP-2 and activated-MMP-2 in KB/COX-2 clones (Fig. 4a). As activated-MMP-2 band was markedly seen in $\mathrm{KB} / \mathrm{COX}-2$ clones, we examined the levels of MT1-MMP, which is known to cleave pro-MMP-2 to yield activated-MMP-2. As a result, expression of MT1-MMP was stronger in $\mathrm{KB} / \mathrm{COX}-2$ clones than in KB/neo clones by Western blot analysis (Fig. 4b). Since the activity of MMP-2 is controlled in at least two ways of proenzyme activation and inhibition of activity by tissue inhibitors of metalloproteinases (TIMPs), levels of TIMP-1 and TIMP-2 were examined, and found that expression of TIMP-1 and TIMP-2 was weaker in KB/COX-2 clones than in $\mathrm{KB} /$ neo clones (Fig. 4b). Rho family small GTPases such as RhoA, Rac1 and Cdc42 involved in cell migration and (a)

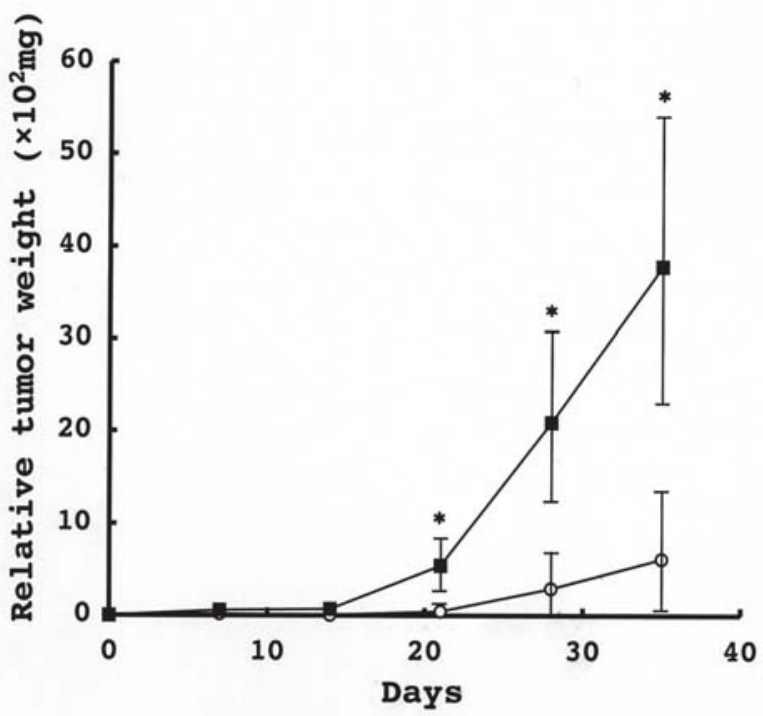

(b)

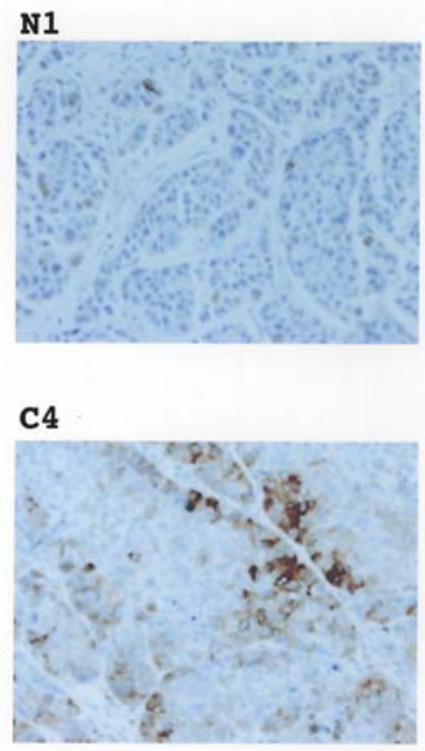

Figure 5. Growth curves of tumors produced by KB/COX-2 (C4) and KB/neo (N1) clones in nude mice and immunohistochemical staining of COX-2. (a) Cells $\left(10^{6}\right)$ were inoculated subcutaneously into the flanks of five 5-week-old female mice (BALB/C nu/nu). Tumors developed at the inoculated sites were measured by using calipers once a week. The relative tumor weight was determined, according to the method of Battelle Columbus Laboratories (23). ○, N1; $\mathbf{m}, \mathrm{C} 4$. ${ }^{*} \mathrm{p}<0.05$. (b) Immunohistochemical staining was performed by a modification of SABC method using anti-human COX-2 rabbit antiserum (IBL, Gunma, Japan). Original magnification, x200. 
N1

(a)

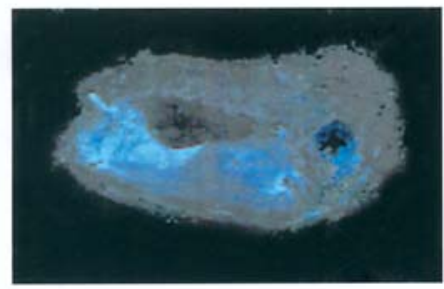

(b)

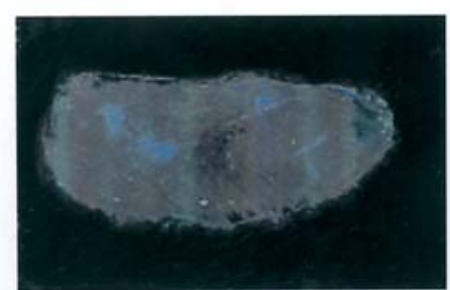

C4
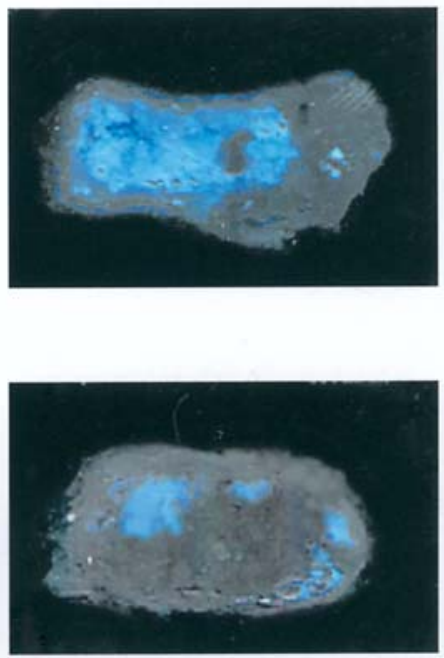

Figure 6. Film in situ zymography of tumor tissues produced by KB/neo (N1) and KB/COX-2 (C4) clones. A 4- $\mu$ m-thick frozen section was placed onto the zymofilm incubated at $37^{\circ} \mathrm{C}$ for $12 \mathrm{~h}$ and stained with $1 \%$ amido black to detect the gelatinase activity. (a) MMP in situ zymography. (b) MMP-PT in situ zymography using a film coated with 1,10-phenanthrolin, an MMP inhibitor.

N1

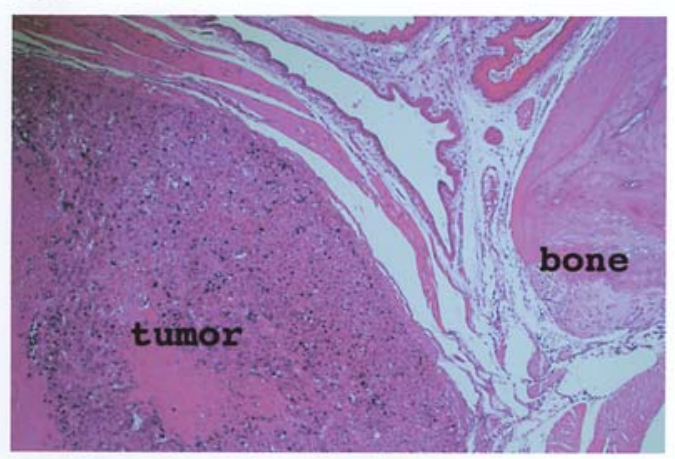

C4

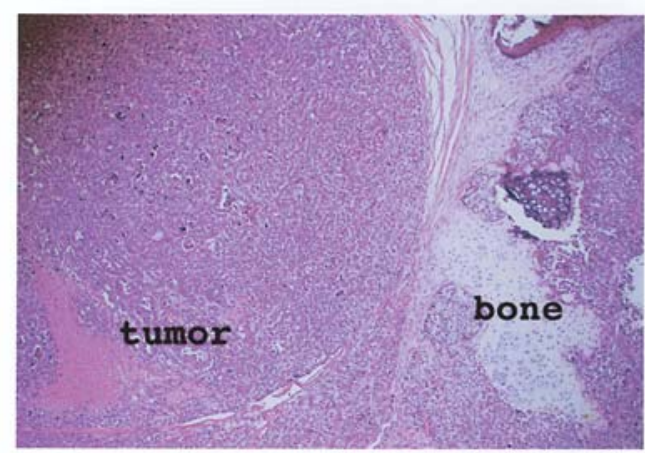

Figure 7. Photomicrographs of tumors produced by orthotopic inoculation of $10^{5}$ cells to the oral floor of nude mice. (N1) Encapsulated tumor produced by $\mathrm{KB} /$ neo (N1) clone. (C4) Tumor produced by KB/COX-2 (C4) clone, showing invasive characteristics with mandibular bone resorption (H\&E stain, original magnification, $\mathrm{x} 40)$.

invasive phenotypes were next examined. Expression of RhoA and Rac1 protein were increased more in $\mathrm{KB} / \mathrm{COX}-2$ clones than in $\mathrm{KB} /$ neo clones by western blot analysis (Fig. 4b), but there was no difference in $\mathrm{Cdc} 42$.

Increased tumorigenicity of $K B / C O X-2$ cells and local invasiveness of their tumors. The tumorigenicity and tumor growth rate in nude mice of $\mathrm{KB} / \mathrm{COX}-2$ clone 4 (C4) and $\mathrm{KB}$-neo clone 1 (N1), which were most different in COX-2 expression, were examined by subcutaneous inoculation of cells. When $10^{5}$ cells were inoculated subcutaneously in the flanks of six nude mice, $\mathrm{C} 4$ produced tumors in all mice, but $\mathrm{N} 1$ produced no tumors. Inoculation of $10^{6}$ cells produced tumors in all five mice in both cell types. Tumors produced by $\mathrm{C} 4$ grew faster than those by $\mathrm{N} 1$ (Fig. 5a) and expressed COX-2 immunohistochemically (Fig. 5b). Film in situ zymography revealed that the gelatinase activity was much stronger in $\mathrm{C} 4$ tumor tissues than in N1 tumor tissues (Fig. $6 a)$. This activity was diminished by the presence of 1,10 - phenanthrolin, an MMP inhibitor (Fig. 6b). To examine the local tumor invasiveness, both cell types were orthotopically inoculated to the oral floor. Consequently, C4 tumors showed invasive character with mandibular bone resorption, whereas N1 tumors showed demarcated margins (Fig. 7).

\section{Discussion}

Overexpression of COX-2 causes excess production of prostaglandins, and induces an increase of cell proliferation and decrease of apoptosis, mostly mediated by $\mathrm{PGE}_{2}$ and its receptor $\mathrm{EP}_{1-4}$ (26). Many studies have indicated significant involvement of COX-2 and $\mathrm{PGE}_{2}$ in carcinogenesis and progression for a variety of cancer (27-29). Furthermore, expression of COX-2 has been reported to contribute to malignant phenotypes such as cancer cell migration, invasion and metastasis $(14,30,31)$. Although several studies have reported increased expression of COX-2 in head and neck carcinoma (16-18), it is not fully understood how COX-2 
contributes to malignant phenotype in squamous cell carcinoma in the majority of head and neck malignancies. Therefore, the present study was designed to investigate the effect of COX-2 overexpression on cancer cell migration, tumorigenicity and invasion, which are fundamental features of malignant phenotype, using the human epidermoid carcinoma KB cell line transfected with COX-2 cDNA. As a result, $\mathrm{KB} / \mathrm{COX}-2$ clones showed elevated $\mathrm{PGE}_{2}$ production as compared to $\mathrm{KB} /$ neo clones, although cell growth rate of these clones was very similar. Nevertheless there was no significant difference in cell growth, cell migration and invasion in $\mathrm{KB} / \mathrm{COX}-2$ clones were significantly increased as compared to $\mathrm{KB} /$ neo clones, as demonstrated by wound healing assay and Matrigel invasion assay. Reorganization of the actin cytoskeleton of the cell is the primary mechanism of cell motility and is essential for most types of cell migration. Actin reorganization is regulated by Rho family small GTPases as Rho, Rac and Cdc42 (32). Slice et al (33) investigated that overexpression of constitutively active mutants of Rho and Rac, but not Cdc42 induced transcription from the COX-2 promoter. In this study, Western blot analysis showed that expression of RhoA and Rac1 but not of Cdc42 in KB/COX-2 clones were stronger than that in $\mathrm{KB} /$ neo clones, supporting the data of Slice et al (33).

Cancer cell invasion has been reported to be promoted by the activation of matrix metalloproteinases (MMPs), especially MMP-2 and MMP-9. MMPs belong to a family of enzymes that degrade the extracellular matrix (ECM) components and are known to contribute to tissue repair, tumor invasion and metastasis. Among them, MMP-2 is secreted as inactive proenzyme, pro-MMP-2. The activation of pro-MMP-2 is thought to take place on the cell surface by MT1-MMP. This process requires both active MT1-MMP and TIMP-2. The amino terminal of TIMP-2 binds to the catalytic domain of MT1-MMP forming a receptor, and the carboxyl terminal of TIMP-2 then interacts with the haemopexin domain of MMP-2 forming a ternary complex. The pro-MMP-2 localized on cell surface is cleaved by another molecule of active MT1-MMP. Intimate coordination of these proteins is therefore required to regulate the proteolytic activity of MMP-2. Several reports indicate that increased levels of MMP-2 correlate with invasive properties of certain tumor cell types (34-36). Tsujii et al (14) showed that overexpressing COX-2 increases MMP-2 expression/activation and cellular invasiveness in colon cancer cells. Thus, increased migration and invasiveness correlate with enhanced expression and activation of MMP-2. On the other hand, it has been shown that MMP-9 might play a more important role than MMP-2 in the invasive and metastatic potentials of squamous cell carcinoma of the head and neck (37-39). The correlation between increased TIMP-1 and TIMP-2 levels and decreased aggressiveness of tumors was found in some studies (40-43), but others have reported that TIMPs are up-regulated during invasion in head and neck carcinoma (44-46). Therefore, the expression of TIMPs in relation to the biological behavior of head and neck carcinoma is still controversial. In our study, $\mathrm{KB} / \mathrm{COX}-2$ clones with increased invasive activity demonstrated the activation of MT1-MMP, MMP-2 and MMP-9 and the inhibition of TIMP-1 and TIMP-2 expression. Since Philip et al (34) provided evidence that gelatinolytic activity is increased by inducing MT1-MMP expression via activation of the NF- $\mathrm{B}$ pathway related to COX-2 transcription, the $\mathrm{NF}-\kappa \mathrm{B}$ pathway in $\mathrm{KB} / \mathrm{COX}-2$ clones is now under investigation.

We next examined the tumorigenicity of $\mathrm{KB} / \mathrm{COX}-2$ cells showing increased migration and elevated MMP activity in vitro and the invasive potential of tumors formed in nude mice. $\mathrm{KB} / \mathrm{COX}-2$ cells showed increased tumorigenicity and tumor growth rate although the growth of these cells was similar to that of $\mathrm{KB} /$ neo cells in vitro. In a recent experiment, we found that $\mathrm{KB} / \mathrm{COX}-2$ clone $4(\mathrm{C} 4)$ produced higher amount of VEGF than did KB/neo clone 1 (N1) (data not shown). Therefore, it was speculated that tumor angiogenesis stimulated tumorigenicity and tumor growth in $\mathrm{KB} /$ $\mathrm{COX}-2$ clone as compared to $\mathrm{KB} /$ neo clone. Furthermore, $\mathrm{KB} / \mathrm{COX}-2$ tumors demonstrated strong invasiveness with mandibular bone resorption in orthotopic inoculation. This finding was supported by the result of the film in situ zymography that the gelatinase activity was expressed stronger in $\mathrm{KB} / \mathrm{COX}-2$ tumor tissues than in $\mathrm{KB} /$ neo tumor tissues.

In summary, our results demonstrate that overexpression of COX-2 elevated cell migration in vitro and tumorigenicity and local tumor invasion in vivo via up-regulated MMP and Rho family small GTPases and down-regulated TIMP activities in human KB carcinoma cell line; hence it is strongly suggested that COX-2 regulating malignant phenotype could become a potent therapeutic target for head and neck carcinoma.

\section{Acknowledgements}

This study was supported by a Grant-in-Aid for Scientific Research from the Ministry of Education, Sports, Science and Culture of Japan to M.U. (No. 15390630), K.T. (No. 16791274) and K.S. (No. 15592148).

\section{References}

1. Vane J: Towards a better aspirin. Nature 367: 215-216, 1994.

2. Kargman SL, O'Neill GP, Vickers PJ, Evans JF, Mancini JA and Jothy S: Expression of prostaglandin $\mathrm{G} / \mathrm{H}$ synthase-1 and -2 protein in human colon cancer. Cancer Res 55: 2556-2559, 1995.

3. Ristimaki A, Honkanen N, Jankala H, Sipponen P and Harkonen M: Expression of cyclooxygenase-2 in human gastric carcinoma. Cancer Res 57: 1276-1280, 1997.

4. Parrett ML, Harris R, Joarder FS, Ross MS, Clausen KP and Robertson FM: Cyclooxygenase-2 gene expression in human breast cancer. Int J Oncol 10: 503-507, 1997.

5. Hida $\mathrm{T}$, Yatabe $\mathrm{Y}$, Achiwa $\mathrm{H}$, et al: Increased expression of cyclooxygenase 2 occurs frequently in human lung cancers, specifically in adenocarcinomas. Cancer Res 58: 3761-3764, 1998.

6. Zimmermann KC, Sarbia M, Weber AA, Borchard F, Gabbert HE and Schror K: Cyclooxygenase-2 expression in human esophageal carcinoma. Cancer Res 59: 198-204, 1999.

7. Tucker ON, Dannenberg AJ, Yang EK, et al: Cyclooxygenase-2 expression is up-regulated in human pancreatic cancer. Cancer Res 59: 987-990, 1999.

8. Shirahama T: Cyclooxygenase-2 expression is up-regulated in transitional cell carcinoma and its preneoplastic lesions in the human urinary bladder. Clin Cancer Res 6: 2424-2430, 2000.

9. Yoshimura R, Sano H, Masuda C, et al: Expression of cyclooxygenase-2 in prostate carcinoma. Cancer 89: 589-596, 2000. 
10. Muller-Decker K, Scholz K, Marks F and Furstenberger G: Differential expression of prostaglandin $\mathrm{H}$ synthase isozymes during multistage carcinogenesis in mouse epidermis. Mol Carcinog 12: 31-41, 1999.

11. Tsujii M and DuBois RN: Alterations in cellular adhesion and apoptosis in epithelial cells overexpressing prostaglandin endoperoxide synthase 2. Cell 83: 493-501, 1995.

12. Huang M, Stolina M, Sharma S, et al: Non-small cell lung cancer cyclooxygenase-2-dependent regulation of cytokine balance in lymphocytes and macrophages: up-regulation of interleukin 10 and down-regulation of interleukin 12 production. Cancer Res 58: 1208-1216, 1998.

13. Tsujii M, Kawano S, Tsuji S, Sawaoka H, Hori M and DuBois RN: Cyclooxygenase regulates angiogenesis induced by colon cancer cells. Cell 93: 705-716, 1998 .

14. Tsujii M, Kawano S and DuBois RN: Cyclooxygenase-2 expression in human colon cancer cells increases metastatic potential. Proc Natl Acad Sci USA 94: 3336-3340, 1997.

15. Leong J, Hughes-Fulford M, Rakhlin N, Habib A, MacLouf J and Goldyne ME: Cyclooxygenases in human and mouse skin and cultured human keratinocytes: association of COX-2 expression with human keratinocyte differentiation. Exp Cell Res 224: 79-87, 1996.

16. Mestre JR, Subbaramaiah K, Sacks PG, et al: Retinoids suppress epidermal growth factor-induced transcription of cyclooxygenase- 2 in human oral squamous carcinoma cells. Cancer Res 57: 2890-2895, 1997.

17. Chan G, Boyle JO, Yang EK, et al: Cyclooxygenase-2 expression is up-regulated in squamous cell carcinoma of the head and neck. Cancer Res 59: 991-994, 1999.

18. Nishimura G, Yanoma S, Mizuno H, Kawakami K and Tsukuda M: A selective cyclooxygenase-2 inhibitor suppresses tumor growth in nude mouse xenografted with human head and neck squamous carcinoma cells. Jpn J Cancer Res 90: $1152-1162,1999$

19. Eagle H: Propagation in a fluid medium of a human epidermoid carcinoma, strain KB. Proc Soc Exp Biol Med 89: 362-64, 1995.

20. Tatebe S, Sinicrope FA and Kuo MT: Induction of multidrug resistance proteins MRP1 and MRP3 and $\gamma$-glutamylcysteine synthetase gene expression by non-steroidal anti-inflammatory drugs in human colon cancer cells. Biochem Biophys Res Commun 290: 1427-1433, 2002.

21. Kishimoto H, Wang Z, Bhat-Nakshatri P, Chang D, Clarke R and Nakshatri H: The p160 family coactivators regulate breast cancer cell proliferation and invasion through autocrine/ paracrine activity of SDF- $1 \alpha / \mathrm{CXCL} 12$. Carcinogenesis 26 : $1706-1715,2005$

22. Hashitani S, Urade M, Nishimura N, et al: Apoptosis induction enhancement of anticancer drugs by celecoxib, a selective cyclooxygenase- 2 inhibitor, in human head neck carcinoma cell lines. Int J Oncol 23: 665-672, 2003.

23. Ovejera AA, Houchens DP and Baker AD: Chemotherapy of human tumor xenografts in genetically athymic mice. Ann Clin Labo Sci 8: 50-56, 1978.

24. Wood GD and Warnke R: Suppression of endogenous avidin binding activity in tissue and its relevance to biotin-avidin detection system. J Histochem Cytochem 83: 1196-1204, 1981.

25. Sakurai K, Urade M, Noguchi K, et al: Increased expression of cyclooxygenase- 2 in human salivary glands tumors. Pathol Int 51: 762-769, 2001.

26. Takahashi $\mathrm{M}$ and Wakabayashi $\mathrm{K}$ : Gene mutations and altered gene expression in azoxymethane-induced colon carcinogenesis in rodents. Cancer Sci 95: 475-480, 2004.

27. Tucker ON, Dannenberg AJ, Yang EK, et al: Cyclooxygenase-2 expresion is up-regulated in human pancreatic cancer. Cancer Res 59: 987-990, 1999

28. Wolff H, Saukkonen K, Anttila S, Karjalainen A, Vainio H and Ristimaki A: Expression of cyclooxygenase-2 in human lung carcinoma. Cancer Res 58: 4997-5001, 1998

29. Mohammed SI, Knapp DW, Bostwick DG, et al: Expression of cyclooxygenase-2 (COX-2) in human invasive transitional cell carcinoma (TCC) of the urinary bladder. Cancer Res 59: $5647-5650,1999$
30. Ito H, Duxbury M, Benoit E, et al: Prostaglandin E2 enhances pancreatic cancer invasiveness through an Ets-1-dependent induction of matrix metalloproteinase-2. Cancer Res 64 : 7439-7446, 2004

31. Rafael M, Amalia FM, Lisardo Bosca and Paloma MS: Prostaglandin E2 promotes migration and adhesion in hepatocellular carcinoma cells. Carcinogenesis 26: 753-761, 2005.

32. Yamazaki D, Kurisu S and Takenawa T: Regulation of cancer cell motility through actin reorganization. Cancer Sci 96: 379-386, 2005

33. Slice LW, Bui L, Mak C and Walsh JH: Differential regulation of COX-2 transcription by Ras- and Rho-family of GTPases. Biochem Biophys Res Commun 276: 406-410, 2000.

34. Philip S, Bubule A and Kundu GC: Matrix metalloproteinase-2 Mechanism and regulation of NF- $\mathrm{kB}-$ mediated activation and its role in cell motility and ECM-invasion. Glycoconj J 21 : 429-41, 2004.

35. Cockett MI, Murphy G, Birch ML, et al: Matrix metalloproteinases and metastatic cancer. Biochem Soc Symp 63: 295-313, 1998.

36. Kawamata H, Kameyama S, Kawai K, et al: Marked acceleration of the metastatic phenotype of a rat bladder carcinoma cell line by the expression of human gelatinase A. Int J Cancer 63 568-575, 1995 .

37. O-charoenrat P, Modjtahedi H, Rhys-Evans P, Court WJ, Box GM and Eccles SA: Epidermal growth factor-like ligands differentially up-regulate matrix metalloproteinase- 9 in head and neck squamous carcinoma cells. Cancer Res 60: 1121-1128, 2000.

38. Hong SD, Hong SP, Lee JI and Lim CY: Expression of matrix metalloproteinase-2 and -9 in oral squamous cell carcinomas with regard to the metastatic potential. Oral Oncol 36: 207-213, 2000.

39. O-charoenrat P, Rhys-Evans P and Eccles SA: Expression of matrix metalloproteinases and their inhibitors correlates with invasion and metastasis in squamous cell carcinoma of the head and neck. Arch Otolaryngol Head Neck Surg 127: 813-820, 2001.

40. Polette M, Clavel C, Birembaut P and De Clerck YA: Localization by in situ hybridization of mRNAs encoding stromelysin 3 and tissue inhibitors of metalloproteinases TIMP-1 and TIMP-2 in human head and neck carcinomas. Pathol Res Pract 189: 1052-1057, 1993.

41. Charous SJ, Stricklin GP, Nanney LB, Netterville JL and Burkey BB: Expression of matrix metalloproteinases and tissue inhibitors of metalloproteinases in head and neck squamous cell carcinoma. Ann Otol Rhinol Laryngol 106: 271-278, 1997

42. Ikebe T, Shinohara M, Takauchi H, et al: Gelatinolytic activity of matrix metalloproteinase in tumor tissues correlates with the invasiveness of oral cancer. Clin Exp Metastasis 17: 315-323, 1999.

43. O-charoenrat P, Rhys-Evans P, Modjtahedi H, Court W, Box G and Eccles S: Overexpression of epidermal growth factor receptor in human head and neck squamous cell carcinoma cell lines correlates with matrix metalloproteinase- 9 expression and in vitro invasion. Int J Cancer 86: 307-317, 2000

44. Sutinen M, Kainulainen T, Hurskainen T, et al: Expression of matalloproteinases (MMP-1 and MMP-2) and their inhibitors (TIMP-1, -2 and -3) in oral lichen planus, dysplasia, squmous cell carcinoma and lymph node metastasis. Br J Cancer 77: 2239-2245, 1998.

45. Kurahara S, Shinohara M, Ikebe T, et al: Expression of MMPs, MT1-MMP, and TIMPs in squmous cell carcinoma of the oral cavity: correlations with tumor invasion and metastasis. Head Neck 21: 627-638, 1999.

46. Culhaci N, Metin K, Copcu E and Dikicioglu E: Elevated expression of MMP-13 and TIMP-1 in head and neck squamous cell carcinomas may reflect increased tumor invasiveness. BMC cancer (Serial online) (Cited 3 August 2004). Available from: http://www.biomedcentral.com /1471-2407/4/42. 